\title{
BROWNFIELD SITES - BETWEEN ABANDONMENT AND REDEVELOPMENT CASE STUDY: CRAIOVA CITY
}

\author{
Georgiana Popescu, Roberto Pătrăşcoiu*
}

University of Bucharest, Faculty of Geography, Simion Mehedinți Doctoral School, Bucharest, Romania

\begin{abstract}
This paper addresses the problem of Brownfield sites in Craiova City. The brownfield sites are of primary importance because they do not only influence the natural environment but also have socio-economic influences on the city in broad meaning: problems in attracting investors, decreasing the attractiveness of real estate properties, the increased rate of unemployment or the consumption of greenfields. Despite this, there is a lack or insufficient information among the decision makers. The general urban plan of Craiova City does not identify the existence of any brownfield site. Moreover, the official planning papers developed by the local authorities (such as The Local Development Strategy and the Integrated Plan for Urban Development) make no references to the brownfield sites. In this respect, the first part of the papers addresses the concept of brownfield and also identifies and maps the types of brownfields in Craiova. Based on specific and relevant case studies, the second part is critically examining the evolution patterns of the brownfield sites within the last decades. Specific management solutions for the reuse and redevelopment of the brownfield sites are also put forward. The paper addresses primarily the and use planners, in order to provide them with a better understanding of what brownfield site are, their nature, scale and patterns.
\end{abstract}

Key words: Brownfield, Previously developed land, Derelict industrial zones, Redevelopment, Land use.

Article Info: Manuscript Received: February 25, 2012; Revised: May 5, 2012; Accepted: May 15, 2012; Online: May $29,2012$.

\section{Introduction}

The research areas of spatial planning and in particular those related to urban planning in the USA and UK have recurrently come to use the term of brownfield in an attempt to describe a certain territorial reality. In reality this is a complex issue with a whole process of conceptualization and difficulties in determining precise definitions especially in contrast with associated terms such as, vacant land, or ' derelict land'. Analysis regarding the origin and evolution of the concept, Smith (2002) estimated that this was first used in the USA in 1995. In 1999, the term was already referenced for 13 times in the academic debates. In the 21st century, the concept has become popular especially in Europe where there are the most concernments in the attempt of theorizing it. Currently the non-

\footnotetext{
${ }^{*}$ Corresponding author:

Address: University of Bucharest, Faculty of Geography, 1, Nicolae

Balcescu Avenue, o10041, Bucharest, Romania

Telephone: +4.0743.073.939

Email: roberto_ptrs@yahoo.com
}

governmental organizations affiliated with the EU, CABERNET (Concerted Action on Brownfields and Economic Regeneration) and CLARINET (Contaminated Land Rehabilitation Network for Environment Technologies) are authorities in the field of understanding and asserting this concept.

Although the concept of brownfield in the USA is just a term to describe the lands affected or potentially affected by contamination (Nathanail et al, 2003), Alker (200o) considered that brownfield is any land that was formerly used in certain economic sectors which currently are no longer in use. Therefore a site cannot be used immediately without external intervention.

Influenced by the studies undertaken by Alker, both CABERNET and CLARINET have adopted the same definition, considering that brownfield means a site which: has been affected by its previous use (e.g.: industrial area, harbour area), is currently abandoned, has real or supposed contamination problems, it usually is located within urban areas and requires interventions to be reintroduced in the economic circuit (CLARINET , 2007) 
This definition is very close to what in the UK is referred as previously developed land, namely any land that has been or is occupied by a permanent structure, which currently is abandoned or unoccupied. Other similar concepts or integrated into that of brownfield have been submitted, the most mentioned being that of derelict land (abandoned land) as it had been a complex process to be defined and referring mainly to the idea of land which cannot be redeveloped without some form of remedial intervention. The practice of EU countries showed that the most typical example of brownfield is that of a derelict industrial area which draws attention to the effects of economic restructuring on urban space and economy.

Although studied thoroughly, in countries with a substantial industrial past (such as UK, USA, Belgium or Germany), the brownfield concept has been rarely approached as such, in the urban and territorial planning researches in Romania.

The brownfield issue has been considered especially in some papers that approached the deindustrialization phenomenon, either from geographical or from urban sociology perspectives. It is worth noting important researches such as Popescu, C (2003) 'Dezindustrializare, reindustrializare și dezvoltare economică' and Chelcea, L (2008) Bucurestiul post-industrial: memorie, dezindustrializare si regenerare urbană. Here, the brownfield sites are not conceptualized though; the research is mainly conducted from a qualitative point of view of the industrial landscape that has bee generated as a result of the deindustrialization (the so-called obsolete industrial grounds "maidan industrial" as metaphorically named by Chelcea, 2008)

An applied analysis of brownfield sites is made by Bruno and Andresoiu (ed, 2007) in „Kombinat. Ruinele industriale ale epocii de Aur". The edited volume attempts a first inventory of the most significant derelict industrial brownfield sites in Romania. The analysis only describes the industrial landscapes and, in some points, proposes design solution for regeneration. A more detailed approach of the brownfield sites is made by Bianca Cobarzan (2007) in "Brownfield redevelopment in Romania”. The study is essentially within the field of urban management and public administration and addresses primarily the tools to encourage stakeholders to make use of these lands.

\section{Understanding the concept in the EU countries and in Romania}

A study conducted by CABERNET (2007) in the European Union countries was undertaken in order to quantify the space occupied by such brownfield sites and also to establish a definition of the concept for each country, Table 1 shows that in most of Europe the existence of these sites has been recognized as a problem, but the brownfield term denotes different meanings from one country to another.

Table 1. Understanding the concept of brownfield in selected EU countries

Austria: No official definition. Understanding similar to CABERNET definition recognising potential for reuse and with less focus on contamination

Belgium Wallonia: Sites previously dedicated to economic activities and where the current condition is contrary to 'efficient land use' (Sites d'activité economique désaffectés - SAED)

Belgium Flanders: Abandoned or under used industrial sites with an active potential for redevelopment or expansion but where redevelopment or expansion is complicated by a real or perceived environmental contamination (legislation including a definition is in the process of approval).

Bulgaria: Contaminated sites - areas where previous activities have ceased but are still impacting on neighbouring areas.

France: Space previously developed that are temporarily or definitely abandoned following the cessation of activity and need to be reclaimed for future use. Can be partially occupied, derelict or contaminated

Netherlands: Areas in towns and cities where in the past industrial activity has taken place, but which have since fallen into disuse

Romania Polluted lands (soils).

Slovenia Degradated / abandoned building land usually inside urban areas.

Spain Basque Country only: Potentially contaminated sites / Industrial ruins

England and Wales : Previously developed land - land which is or was occupied by a permanent structure (excluding agricultural or forestry buildings), and associated fixed surface infrastructure.

Source: CABERNET, 2007

A brief analysis of these definitions reveals that most European countries understand the brownfield sites either as contaminated lands (Bulgaria, Romania) or as abandoned lands that may have contamination issues (UK, Slovenia, France, England, Belgium). In Romania it seems that this concept has been poorly understood, since the complex concept of brownfield was assimilated with that of polluted soil by the Ministry of Environment. That is why Romania is listed as the European country with the highest density of brownfield sites.

Associating the concept of brownfield with that of polluted soil and assimilating it with the later implies on one hand large theoretical reserves and on the other a more complex debate. Hence this paper considers as being entitled the definition of the EU 
on the matter. Moreover, in Romania there are no official government led studies on this phenomenon, consequently no financial or legal policy framework in this area let alone procedures and regulations. In this respect Craiova City is a specific case study due to its both polluted soil situation and brownfields.

\section{The need to identify the brownfield sites in Craiova city}

Identifying the brownfield sites form a certain locality is a prime tool in supporting the planning and marketing activities of a site. On the other hand the lack of data on brownfield sites is a decisive obstacle to their redevelopment. There are several reasons for which there is a significant need of identifying and mapping the brownfield sites of Craiova City. Among the most important ones are, the fact that until 2012 there has not been conducted any study of identifying and mapping of the brownfield sites. However, this should be a subject investigated in detail in terms of reuse opportunities, and their reintegration into the economic circuit. Also, in Romania the concept has not been understood as such, therefore the Ministry of Environment assimilated the brownfield sites with the polluted soils. This definition is too broad and does not capture the essence of the concept as it is understood in the EU. Another reason is that during the last 17 years Craiova municipality has experienced profound changes of the economic features. The economic crisis, the failure of oversized industrial enterprises to face the new market economy and the reluctance of investors to invest in Craiova City industry has resulted in the development of some compact built areas next to areas of redundant infrastructure. The brownfield sites not only influence the natural environment but also have socio-economic influences on the city - in broad meaning: problems in attracting investors, decreasing the attractiveness of real estate properties, the increased rate of unemployment, the consumption of greenfields - and which represent the free lands, unaffected by the previous use. In addition to the above mentioned reasons there is also the lack or insufficient information among the decision makers. The general urban plan does not identify the existence of any brownfield sites. Moreover, certain areas (which in reality are brownfield sites) are still mapped according to their previous functionality. Some lands are still listed as industrial areas although they have lost this feature long ago. The local regional development strategy of Craiova municipality developed in February 2006 by Craiova City Hall, and also the Integrated Plan for Urban Development developed in 2010 by the same authorities make no references to the brownfield sites

\section{The methodology in the identification of brownfield sites}

A first step in identifying the brownfields in Craiova municipality was their definition. For more accuracy this paper refers to the definition given by entitled the EU bodies. Brownfields is a site which: has been affected by a previous use (e.g.: industrial area); is currently abandoned; has real or supposed contamination problems and requires interventions to be reintroduced in the economic circuit.

The study area was established on the basis of the general urban plan analysis. From the functional areas identified in GUP: central nucleus, residential areas, industrial areas, the agricultural economic units, green areas, the railway and construction areas, commercial area, the public institutions area and cemeteries. The green areas and the cemeteries which according to the definition cannot be assigned to areas that were the subject of an economic use in the past, and have been removed from the research area .

The identification of the current functionality of the built elements from the study areas was accomplished by visiting the sites. Mapping the identified brownfields was done with the help of the high-resolution satellite images of Craiova and with the General Urban Plan.

\section{The typology of brownfield sites within Craiova city}

The research conducted revealed that there are three types of brownfield sites (Figure 1). Also, the identification study of the brownfield sites revealed as a major cause of their occurrence the phenomenon of economic restructuring and deindustrialization. The two conjugated phenomena have led to the socalled "previously developed land", meaning lands that have previously been developed but which are currently abandoned and have no functionality.

\section{Derelict industrial areas}

During communism, oversized industrial areas in Craiova municipality were constructed. In 1990 nearly 25 percent of urban land area was occupied by industrial units (Figure 2) and $85.5 \%$ of the turnover of Craiova industry was owned by large and very large companies (Dolj Chamber of Commerce and Industry, 2003). After 1990, the economic crisis and the transition to a market economy, and the investors' reluctance to develop projects inside the industrial areas have gradually led to the emergence of some derelict industrial areas with redundant infrastructure and buildings. 


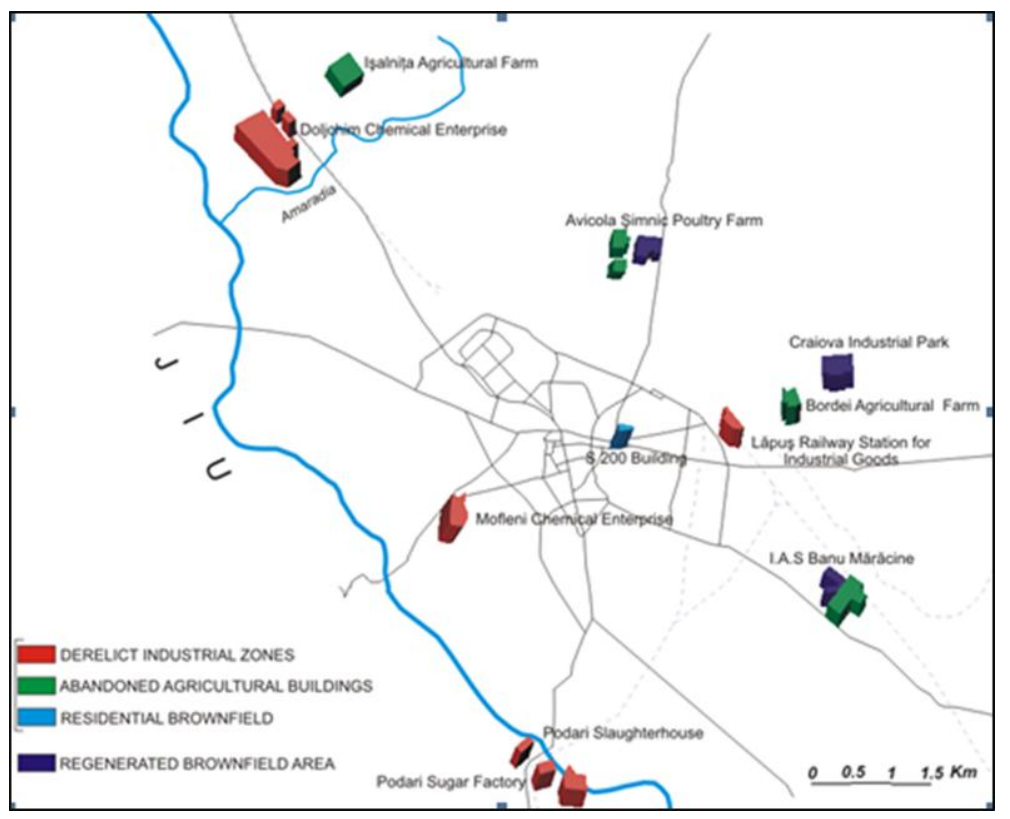

Figure 1. The typology and location of brownfield sites in Craiova City, 2012

These brownfields appearance has been accompanied by social phenomena such as unemployment. The Regional Directorate of Statistics figures show that the average number of employees in industry has halved since the post-communist period.

There have been identified the following abandoned areas or industrial units:

- Podari Slaughterhouse (as part of the Podari industrial area)
- Podari Sugar Factory (as part of the Podari industrial area)

- Most of the Doljchim chemical enterprise

- Most of the Mofleni chemical enterprise

- Lapus Railway Station for industrial goods

\section{Unoccupied or abandoned agricultural buildings}

The collectivization and systematization of

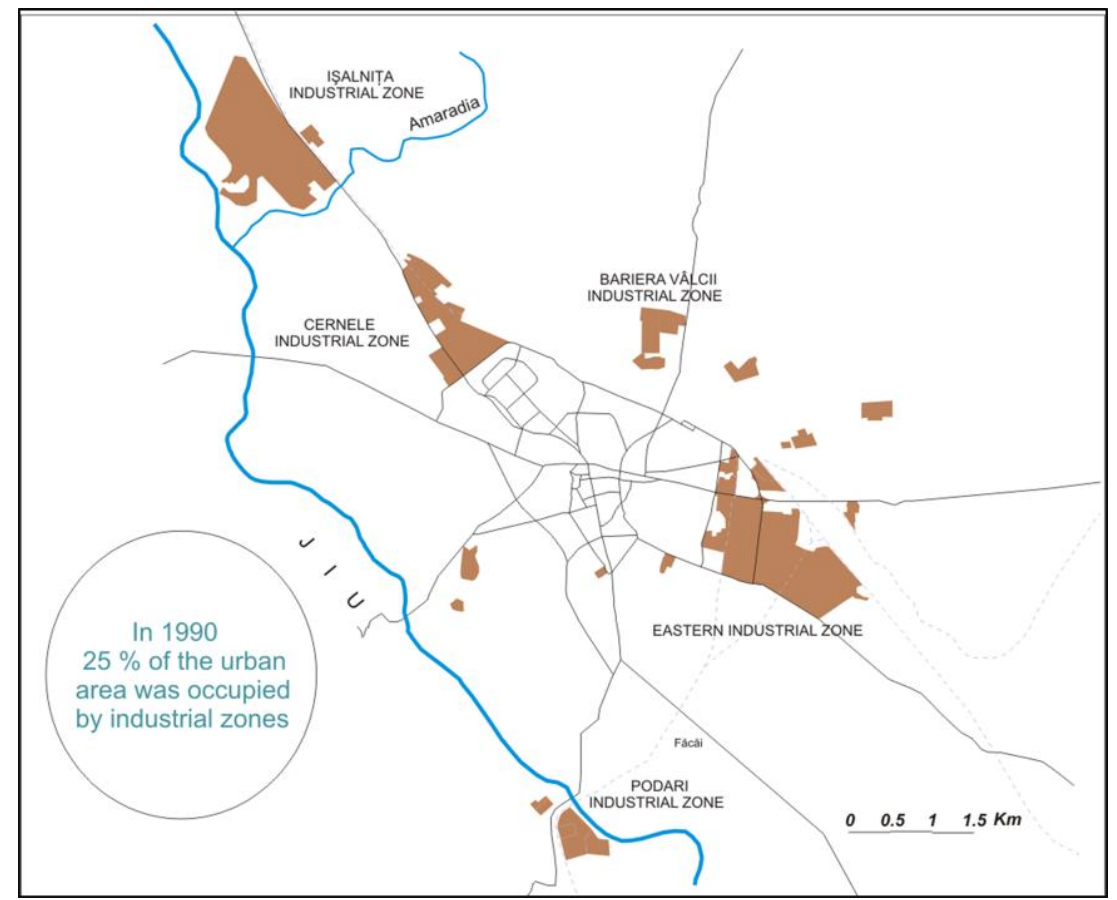

Figure 2. The industrial areas of Craiova municipality in 1990 Source: Developed on the cartographic base of Craiova General Urban Plan 
agriculture and industrial output during communism led to the construction of standardized assemblages of agricultural economic units of SAE type (State Agricultural Enterprise) within Craiova administrative areas. The total restructuring of the Romanian agriculture in the early '9os produced significant changes in the functionality of these areas so that at present none of the built agricultural structures during the communist period has not been maintained. Moreover some units do not have any use.

Currently these units from the mentioned category along with the related infrastructure can be considered brownfields: Eastern half side of Banu Maracine SAE; Bordei agricultural farm; Sections 3 and 4 of the Bariera Valcii poultry farm and Isalnita Farm

\section{Residential Brownfield}

Brownfield sites from the category of abandoned residential structures and areas are rare in Romania and are especially characteristic to certain rural areas facing the process of depopulation. In Craiova there is only one example of residential brownfield, represented by the $\mathrm{S} 200$ collective dwellings located at the crossroads of Calea Bucuresti and A.I. Cuza Streets. During communism it was intended to build here a huge hotel, the largest in the south of the country. Due to the lack of funds the building has changed into block of flats, which included 200 studio apartments and two-bedroom flats. Although the building was built it was never used, having currently the appearance of a huge building site located in Craiova City Center.

\section{REUSE ADVANTAGE AND MANAGEMENT SOLUTIONS FOR BROWNFIELD SITES IN CRAIOVA CITY}

Most of the brownfield sites of Craiova City are caught in a certain vicious cycle of decline. The remediation costs of these sites are high and thereby they are let to deteriorate. On the other hand, these vacant facilities invite illegal dumping, and vandalism. As a consequence, potential investors faced with uncertain costs and legal liabilities seek development opportunities elsewhere.

The discussions over the use of the brownfield sites are divided into two opposite and clear directions: demolition of the built area included within the brownfield and land reuse and redevelopment of brownfields, in this way the list of urban concepts including various terms such as

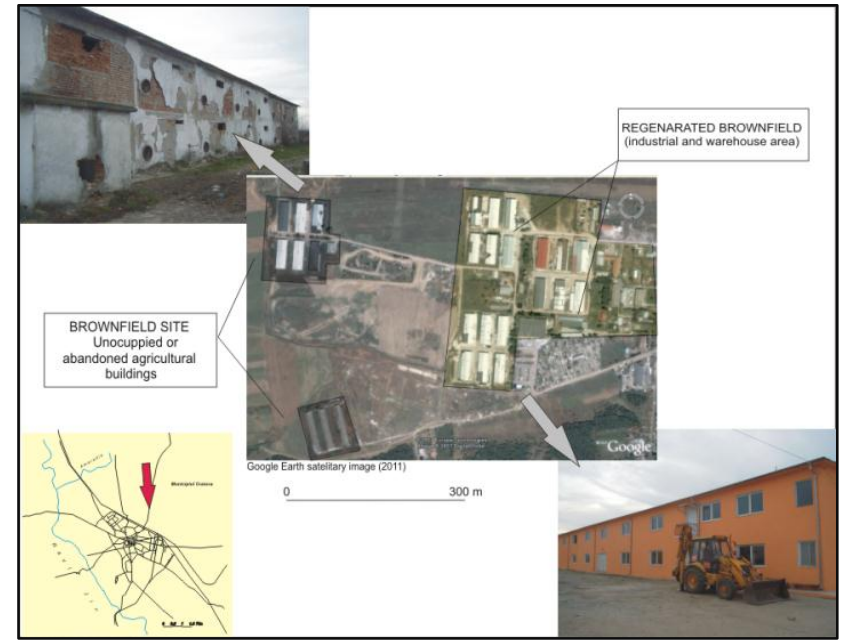

Figure 3. The brownfield sites in Avicola Șimnic, 2011

renovation, restoration, revitalization, recycling, regeneration or rehabilitation.

In Craiova City, the redevelopment of the brownfield sites could lead to solving some urban, socio-economic and ecological problems. Among the advantages and management solutions in terms of brownfield redevelopment it is worth mentioning:

balancing the use of greenfield by reusing the brownfield sites. In Craiova municipality the concerns for reusing the brownfields are almost nonexistent, although in the last decade the urban sprawl process, resulted in the extension of residential, industrial or commercial areas to the periphery, use more and more greenfield, while the brownfields remain unused. Also functional and design improvement of spaces by removing the abandoned spaces is an important step in the process of urban renovation. Creating job opportunities locally, preserving the industrial heritage and finding new uses for industrial buildings with historical value (open-air industrial museums) could be another advantage. Germany, Holland and England came up with the idea of turning to tourism to revitalize the abandoned industrial areas. For instance, the coal mines in Essen (Zollverein XII) together with other industrial landscapes from the Ruhr region were included in the UNESCO World Heritage list. The Isalnita Chemical Plant located in the northwest of Craiova and currently abandoned in the most part is a typical example of oversized industrial enterprise from communism. It could be successfully integrated into an eventual project of recovery of Romania's communist heritage, being an open-air industrial museum which could provide an image of the city's industrial past during the communist period. 


\section{Legal framework}

The first aspect that threatens the brownfields redevelopment in Craiova municipality is their legal framework. At local level there is no coherent strategy which includes the issue of brownfield sites. Since there has not even been any concern of at least identifying and mapping these sites, the redevelopment of brownfields becomes challenging. Accessing some European funds would also be viable, in this regard it is worth mentioning the European Regional Development Fund (ERDF) involved in brownfields regeneration actions in Central and Eastern European countries. Within this fund there are special programs developed to assist the conversion of industrial brownfield: URBAN (urban regeneration projects): REGIONAL OPERATIONAL PROGRAM-AXIS 4

\section{Development and prospects}

The evolution prospects of Craiova brownfields sites are difficult to predict because so far there is only a limited feedback regarding their redevelopment. However there are some sites which in recent years have seen some redevelopment. The examples given by these have created two models of redevelopment of brownfields within Craiova municipality.

Self-development is the characteristic of some brownfields which have their own dynamic potential of development and public intervention is not necessary. This self-development occurs when a brownfield has a high value on the market (in terms of its position within the city) and the rehabilitation costs are not high. In Craiova, there are two such examples both including the former SAE farm type structures. In recent years some of the abandoned farms from Banu Maracine and the farms belonging to Avicola Simnic from Bariera Valcii were taken over by private investors who turned them into small units of industrial production or warehouse areas.

Thus half of the brownfield site was represented by the Avicola farms and was turned into a micro industrial and warehouse area while the other half still does not have any use. The situation is more complicated in the brownfield sites represented by the former Banu Maracine farms, where the western half was turned into an industrial and warehouse area on the same principle of private investments. The eastern half remained abandoned, but some buildings deteriorated into a poor quality residential area and were occupied abusively by poor population generating slum types of residential spaces.

Assisted redevelopment is characteristic to some brownfields which have limited development potential, which require administrative interventions from central level to be rehabilitated. In addition, assisted redevelopment is necessary in the case of some brownfields that require massive investments of rehabilitation. Typically, these investments are higher than the benefits which may accrue later. Therefore the private owners are not tempted to rehabilitate these brownfields in the absence of facilities or financial, administrative incentives etc.

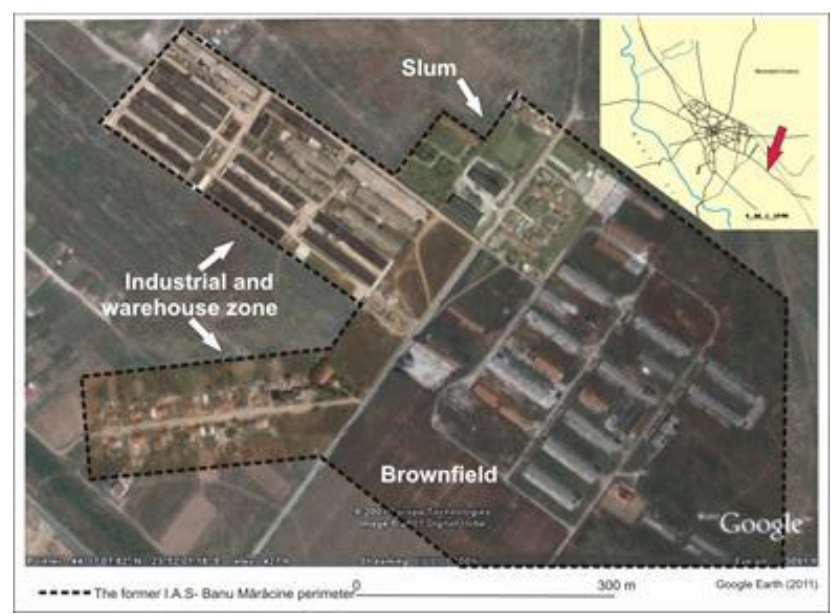

Figure 4. Changes in the space functionality at Banu Maracine SAE, 2011

In Craiova there is only one previous example of assisted redevelopment of a brownfield, the Craiova Industrial Park. The industrial park was created in 2006 on the ruins of the former aircraft construction enterprise. It provides a viable model for recycling the former industrial space, currently each room of the old enterprise being designated to various Small and Medium Sized Enterprises. For example, in a former warehouse of the aircraft construction enterprise there is a textile factory now; which is working for export to EU countries and in a former room of metal processing there is now a factorymaking radiators. Also the Craiova industrial park project is a model for organizing and providing administrative and tax incentives for the reuse of abandoned industrial areas. These facilities refer to the fact that the company that manages the industrial park has a share of $20 \%$ which is deducted from the taxable income in return for offering the necessary infrastructure and space to the companies from the industrial park.

Another assisted redevelopment project of a brownfield is related to the creation of a University IT Technology Park to use the abandoned building represented by the S2oo block (Figure 5)

The project was adopted in 2006 and the financing costs have been secured by a loan of $\$ 12$ million USD granted by the Ministry of Education and Research to the University of Craiova, which owns the S2oo building. The complex will have an exhibition space and a conference center, five floors 
dedicated to the research and development activity of the University of Craiova in the IT field and also offices available to resident companies. It is intended that the resident companies to be of more than $50 \%$ of the ICT companies field (University of Craiova, 2007).

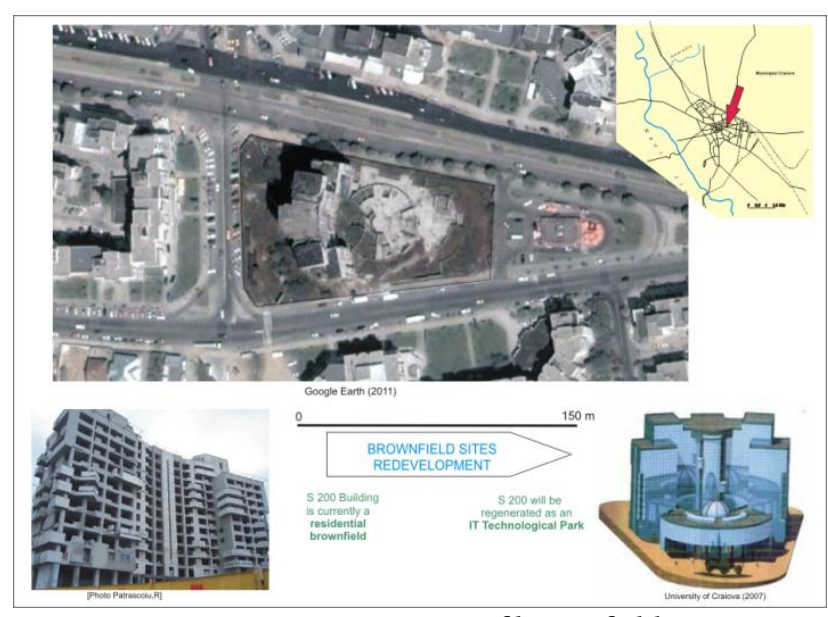

Figure 5. Regeneration Projects of brownfield sites, 2011

\section{Conclusions}

The Brownfield sites represent a territorial reality in Craiova City. The brownfield sites not only influence the natural environment but also have socio-economic influences on the city in broad meaning: problems in attracting investors, decreasing the attractiveness of real estate properties, the increased rate of unemployment or the consumption of greenfields. Despite this, there is a lack or insufficient information among the decision makers. The general urban plan does not identify the existence of any brownfield site. Moreover, the official planning papers developed by the local authorities (such as The Local Development Strategy and the Integrated Plan for Urban Development) make no references to the brownfield sites. In this respect, the defining, identifying and mapping of the brownfield sites in Craiova City is prime tool in supporting the planning and potential redevelopment of these sites. The study has identified and mapped the three types of brownfield (derelict industrial zones, abandoned agricultural buildings and residential brownfield) and also analyses the advantages of brownfield redevelopment. Balancing the use of green fields, creating job opportunities and preservation of industrial heritage are just few examples in this direction.

The evolution prospects of Craiova brownfields are difficult to predict because so far there is only a limited feedback regarding their redevelopment. However there are some sites which in recent years have seen some redevelopment. The examples given by these, have created two models of redevelopment of brownfields within Craiova municipality. The selfdevelopment is the characteristic of some brownfields which have their own dynamic potential of development (such as the Avicola Simnic and Banu Maracine examples). On the other hand the assisted redevelopment is characteristic to some brownfields that require massive investments of rehabilitation (such as the Craiova Industrial Park and S 200 building)

\section{References}

Alker, 200o, 'The Definition of Brownfield', Journal of Environmental Planning and Management 43(1).

Bruno, A 2007, Kombinat. Ruine industriale ale Epocii de Aur, Editura: Igloo Media, Bucuresti

CABERNET (Concerted Action on Brownfields and Economic Regeneration) 2007, The Scale and Nature of European Brownfields, www.cabernet.org.uk/resourcefs/417.pdf

Chelcea, L 2008, Bucurestiul post-industrial: memorie, dezindustrializare si regenerare urbană, Ed Polirom, Iasi

CLARINET (Contaminated Land Rehabilitation Network for Environment Tehnologies) 2007, Brownfields and Redevelopment of Urban Areas, www.clarinet.at/library/brownfields.pdf

Cobarzan, B 2007, 'Brownfield redevelopment in Romania', Transylvanian Review of Administrative Sciences, 21 E/2007, Cluj-Napoca, pp. 28-46.

Communities and Local Government 2007, Brownfield sitesPlanning Policy Guidance Document $3 \quad P_{3}$, http://www.communities.gov.uk/.

Department of Environment, Transport and the Regions (DETR) 2000, DETR Circular 2/200o: Contaminated Land, The Stationery Office, London.

Directia Regionala de Statistica Dolj n.d, Fisa localitatiiMun Craiova 1990-2002.

Nathanail, P, Thornton, G \& Millar, K 2003, 'What's in a Word: UK and international definitions of "brownfield", Sustain 4 (3)

Netherland Ministry of spatial planning and the Environment 1998, Urban brownfields : restructuring and urban economic development,

http://international.vrom.nl/Docs/internationaal/urban.p $\mathrm{df}$

Popescu, C 2003, 'Dezindustrializare, reindustrializare şi dezvoltare economică' in C Popescu (ed) Disparităţi regionale în dezvoltarea economico-socială a României, Editura Meteor Press, București, pp 118-151.

Primaria Municipiului Craiova 2007, Strategia de dezvoltare locala,

http://www.primariacraiova.ro/pcv/servlet/portal?action $=$ ContentAction\&actEvent $=$ showArticle\&id $=1206$

S.C Proiect S.A n.d., Planul Urbanistic General

Smith, R 2002, 'Compaction of Urban Areas and Shifting Perceptions of Degraded Ground', GBER Vol. 4 No. 3 pp 54-59.

U.S Environmental Protection Agency 2007, Brownfields Cleanup and Redevelopment, http://www.epa.gov/brownfields/about.htm

Universitatea din Craiova 2006, Plan operational, cisol.central.ucv.ro/manag_ac_ad/files/plan_operational_ 2006.pdf 